\title{
The Relationship between Acute and Chronic Pancreatitis with Pancreatic Adenocarcinoma: Review
}

\author{
Tamara Alhobayb ${ }^{1}$ (D), Rahul Peravali ${ }^{2}$ and Motaz Ashkar ${ }^{1, *}$ (i) \\ 1 Department of Medicine, Division of Gastroenterology, School of Medicine, Washington University, \\ St. Louis, MO 63110, USA; tamaraa@wustl.edu \\ 2 Department of Internal Medicine, School of Medicine, Washington University, \\ St. Louis, MO 63110, USA; Peravali.r@wustl.edu \\ * Correspondence: motaz.ashkar@wustl.edu
}

check for updates

Citation: Alhobayb, T.; Peravali, R.; Ashkar, M. The Relationship between Acute and Chronic Pancreatitis with Pancreatic Adenocarcinoma: Review. Diseases 2021, 9, 93. https://doi.org/ $10.3390 /$ diseases 9040093

Academic Editors: Veysel Tahan and Ebubekir S. Daglilar

Received: 16 November 2021 Accepted: 14 December 2021 Published: 20 December 2021

Publisher's Note: MDPI stays neutral with regard to jurisdictional claims in published maps and institutional affiliations.

Copyright: (c) 2021 by the authors. Licensee MDPI, Basel, Switzerland. This article is an open access article distributed under the terms and conditions of the Creative Commons Attribution (CC BY) license (https:/ / creativecommons.org/licenses/by/ $4.0 /)$.

\begin{abstract}
Pancreatic ductal adenocarcinoma (PDAC) is a lethal disease with poor prognosis, leading to significant cancer-related mortality and an overall five-year survival rate of about nine percent. Acute and chronic pancreatitis have been associated with PDAC through common risk factors based on multiple epidemiological studies. Acute pancreatitis (AP) might be one of the earliest manifestations of PDAC, but evolving chronic pancreatitis (CP) following recurrent bouts of AP has been proposed as a risk factor for cancer development in the setting of persistent inflammation and ongoing exposure to carcinogens. This review aims to highlight the evidence supporting the relationship between acute and chronic pancreatitis with PDAC.
\end{abstract}

Keywords: acute pancreatitis; chronic pancreatitis; pancreatic cancer

\section{Introduction}

Burden of pancreatic ductal adenocarcinoma (PDAC) is well-recognized globally, and it is estimated as the 11th most common cancer in the world based on accumulative data from 2018 [1]. PDAC incidence varies across the world, with higher rates in developed populations from North America (7.4 per 100,000 people) and Western Europe (7.3 per $100,000$ people) [1,2]. PDAC is more common in men (4.9 per 100,000$)$ than women (3.6 per $100,000)$ and increases in both sexes with age [1,2]. Importantly, PDAC annual incidence is increasing by $0.5-1.0 \%$ [3], and remains a lethal disease with poor prognosis, leading to significant cancer-related mortality with an overall five-year survival rate of about nine percent [4]. Rapid growth and lack of a reliable screening modality make diagnosing PDAC challenging, which results in disease discovery at advanced incurable stages [4]. By 2030, PDAC is projected to become the second leading cause of cancer-related mortality [3].

PDAC accounts for more than $90 \%$ of all pancreatic tumors [5]. Accumulating evidence suggests that pancreatitis is a risk factor for PDAC. Evolving chronic pancreatitis (CP) following recurrent bouts of acute pancreatitis (AP) has been proposed as risk factor for cancer development in the setting of persistent inflammation and ongoing exposure to carcinogens. Virchow's observation of inflammatory cells within neoplastic tissue suggested correlations between inflammation and future dysplasia [6], proven by development of various cancers from sites of chronic irritation and inflammation, including tumors of the lung, GI tract, skin, and urinary bladder. This review aims to highlight the evidence supporting the relationship between acute and chronic pancreatitis with PDAC.

\section{Association between Pancreatitis and Pancreatic Cancer}

\subsection{Acute Pancreatitis and Pancreatic Cancer}

The association between pancreatitis and pancreatic cancer is well-established, and it is mostly driven by CP. Over the past few decades, there has been an ongoing debate on whether AP carries the same risk of developing pancreatic cancer, and multiple studies 
aimed to quantify such risk. Kirkegard et al. conducted a large nationwide matched cohort study in Denmark, which included 40,000 patients with AP. This work concluded that the risk of PDAC in patients with AP was two-fold higher compared to that in the general population over a 5-10-year follow-up period [7]. These observations were similar to the findings from US studies utilizing the VA system database [8,9]. Bansal et al. published a case-control study including about 2600 veterans with PDAC and noncancer controls. This work demonstrated higher likelihood of having a history of AP preceding PDAC (OR 1.76; 95\% CI: 1.28-2.41) [8]. Another Taiwanese study assessed AP and PDAC association [10] by evaluating 747 hospitalized patients with AP and 5976 controls. This work observed significantly higher five-year risk of developing PDAC in the AP cohort compared to that in controls (HR 9.10; 95\% CI: 3.81-21.76). A large population-based study in Sweden reproduced similar conclusions of elevated PDAC risk in patients with AP in the first few years, but interestingly, this decreased over time [11]. Two meta-analyses were conducted to ascertain the effect of AP and PDAC association. Zhang et al. meta-analysis of four cohort studies estimated a pooled relative risk of 8.30 (95\% CI: 4.27-16.13) [12]. Another meta-analysis of 11 observational studies, suggested higher PDAC incidence after AP with estimated pooled relative risk of 7.81 (95\% CI: 5.00-12.19) [13]. Although these observations highlighted a robust association between $\mathrm{AP}$ and PDAC, the question of whether this is a causal effect or if AP is a presenting symptom of PDAC remains unanswered.

\subsection{Chronic Pancreatitis and Pancreatic Cancer}

Multiple studies have shown that CP is highly associated with PDAC [8,14-20]. A multicenter, retrospective cohort study conducted by the International Pancreatitis Study Group showed that the cumulative risk of PDAC in patients with CP is $1.8 \%$ and $4 \%$ at 10 and 20 years, respectively, a rate which is from 15- to 16-fold greater than that of the general population [14]. Importantly, this risk was independent of sex, ethnicity, and type of pancreatitis (alcoholic and nonalcoholic). A single-center prospective cohort study verified these observations, concluding that $\mathrm{CP}$ patients have higher 5- and 10-year cumulative incidence of developing PDAC $(1.1 \%$ and $1.7 \%)$ compared to that in age- and sex-matched controls [15]. Most convincingly, a meta-analysis of six cohort studies and one case-control study showed a pooled relative risk estimate of 13.3 for PDAC among patients with CP [16], which suggested that about five percent of patients with $\mathrm{CP}$ will develop PDAC within a 20-year follow-up period. These efforts proposed the higher causative association between long-standing $\mathrm{CP}$ and future PDAC development.

\section{Pancreatitis and Pancreatic Cancer Risk Factors Overlap}

The specific cause of PDAC remains elusive, but higher incidence has been observed in cohorts with certain environmental factors (Table 1). Cigarette smoking is highly associated with PDAC with a relative risk between 1.7 and 2.2 [21,22]. The International Agency for Research on Cancer has confirmed that cigarette smoking is causally linked with PDAC [23]. Studies have shown that risk of PDAC is nearly two times higher in smokers than in nonsmokers, and the risk increases with the duration of smoking and number of cigarettes smoked daily [24-26]. Diet is also a risk factor for PDAC. Red or processed meat is associated with increased incidence of PDAC; in contrast, nuts, vegetables, and fruits have been shown to be protective [27-30]. Obesity and diabetes mellitus are also linked to a higher PDAC risk [31-33]. In addition to environmental factors, individuals with inherited genetic disorders (e.g., Lynch syndrome, Li-Fraumeni syndrome, Peutz-Jeghers syndrome, familial adenomatous polyposis) or deleterious mutations in certain genes (e.g., K-ras, p53) carry a significantly increased risk for PDAC [34-36]. 
Table 1. PDAC risk factors.

\begin{tabular}{cc}
\hline Risk Factor & Increased PDAC Risk (RR) \\
\hline BMI > 40 & $2.76[32]$ \\
Type 2 diabetes mellitus & $1.8-2.1[37-39]$ \\
History of gallstones & $1.7[40]$ \\
Current cigarette use & $1.7-2.2[21,22]$ \\
$>3$ alcoholic drinks per day & $1.22[41]$ \\
Acute pancreatitis & $7.81[13]$ \\
Chronic pancreatitis & $13.3[16]$ \\
Hereditary pancreatitis (PRSS1 mutation) & $69[16]$ \\
\hline
\end{tabular}

Detailed epidemiological studies have identified shared risk factors between pancreatitis and PDAC [16,42]. Given the overlapping risk factors, the relationship between pancreatitis and pancreatic cancer can be attributed to confounding. However, studies have shown that pancreatitis increases the risk of PDAC independently of risk factors. For example, one pooled analysis of ten case control studies (5048 cases of PDAC and 10,947 controls) showed a nearly three-fold association between previous pancreatitis and PDAC after controlling for potential confounders and effect-modifying covariates such as smoking history, alcohol intake, BMI, and history of diabetes mellitus [43]. The relationship between $\mathrm{AP}, \mathrm{CP}$, and PDAC is likely continuous, such that pancreatitis is an intermediate stage between normal pancreatic function and PDAC. Conceptually, pancreatic insults from smoking, alcohol abuse, and diabetes increase the risk for AP, and repeated bouts of $\mathrm{AP}$ increases the risk of progression to $\mathrm{CP}$, which in effect can lead to carcinogenesis by fostering an environment that supports tumor formation.

\section{Pathophysiology of Pancreatic Cancer in Pancreatitis}

\subsection{Acute Pancreatitis and Pancreatic Cancer Mechanisms}

Many theories were proposed in order to explain the association between AP and PDAC. The main proposed mechanism is disease progression from acute to recurrent to chronic inflammation, which alters the pancreatic environment and facilitates dysplasia-toneoplasia transition [42]. Another theory is that AP can cause genetic alterations that lead to accelerated formation of PDAC. This was suggested by Carrière et al. who observed that mice expressing oncogenic K-ras had rapid PDAC development after being subjected to two brief episodes of AP [44]. A different mechanistic theory is that AP is actually the first symptomatic presentation of PDAC secondary to tumor ductal obstruction, rather than being a predisposing risk factor [45]. In addition, most of the studies that found a strong association between AP and PDAC found a higher risk in the first two years after AP, after which the risk subsequently decreased. This suggests that AP is not a PDAC cause, but rather the cancer masquerading as inflammation.

\subsection{Chronic Pancreatitis and Pancreatic Cancer Mechanisms}

Carcinogenesis in $\mathrm{CP}$ is mediated by inflammatory processes. Chronic inflammation is characterized by sustained tissue damage, cellular proliferation, and tissue repair [46]. Uncontrolled cellular proliferation can lead to atypical cell production and carcinogenesis [47]. Diseases with chronic inflammation (e.g., Barrett's esophagus, chronic gastritis, ulcerative colitis) have an increased risk of cancer of the affected organ [48]. Similarly, chronic pancreatic inflammation in CP can favor the malignant transformation of pancreatic ductal cells and lead to dysplasia and cancer. The specific cellular mechanisms underlying pathogenesis of pancreatic cancer in $\mathrm{CP}$ are far from clear, but research suggests interactions between inflammatory, proliferatory, and fibrotic pathways. Uncontrolled inflammation of the pancreas leads to activation and recruitment of cytokines and chemokines, which promote a microenvironmental milieu that favors progression from inflammation to malignancy [49]. Additionally, inflammation can enhance the activity of transcription factors, such as nuclear factor kappa B (NF-kB), which upregulate genes that promote carcinogen- 
esis [50]. Inflammation also activates quiescent pancreatic stellate cells, which promote fibrosis and pancreatic injury [51]. Cytokines, transcription factors, and pancreatic stellate cells synergistically work together to promote oncogenesis in CP.

Chronic inflammation activates cytokines that induce localized tissue destruction and organ damage. Several proinflammatory cytokines, such as tumor necrosis factoralpha (TNF- $\alpha$ ), interleukin-6 (IL-6), interleukin-8 (IL-8), and interferon-y (IFN-y), are increased in both $\mathrm{CP}$ and PDAC $[52,53]$. Abnormal cytokine expression in CP can promote pancreatic carcinogenesis via a multitude of mechanisms. TNF- $\alpha$, for example, is a potent cytokine that is released during the early stages of inflammation. In $\mathrm{CP}, \mathrm{TNF}-\alpha$ can upregulate the expression of platelet derived growth factor (PDGF), a growth factor that stimulates fibrogenesis [52]. In addition, TNF- $\alpha$ upregulates transforming growth factoralpha (TGF- $\alpha$ ), an oncogene that can increase cell proliferation and promote cancer [54]. Finally, TNF- $\alpha$ can inhibit the apoptosis of PDAC cells by activating NF-kB, an important transcription factor that has been implicated in many different cancers [55]. IL-6 is another important proinflammatory cytokine that is elevated in CP and PDAC. IL-6 can induce acinar cell damage in mice and has been shown to promote PDAC cell migration and invasion [56]. In one study, blockade of IL-6 resulted in reduced tumor progression in murine models of PDAC [57].

In addition to proinflammatory cytokines, upregulation of certain transcription factors can promote carcinogenesis in CP. NF-kB is upregulated in a significant number of human cancers, including pancreatic, colorectal, and lung cancers $[58,59]$. Under normal conditions, NF-kB is bound to inhibitory proteins (IkBs) that trap the transcription factor in the cytoplasm and keep it inactive. In chronic inflammatory conditions such as $\mathrm{CP}$, the inhibitory proteins are degraded, and NF-kB translocates to the nucleus where it increases the transcription of proteins that promote oncogenesis [60]. Interestingly, NF-kB is associated with increased severity of $\mathrm{CP}$ and is constitutively activated in most PDAC cases $[60,61]$. NF-kB has been implicated in promoting cancer progression via a variety of mechanisms, including increasing cancer cell proliferation and antiapoptotic and inflammatory signals [62]. For example, studies have shown that NF-kB promotes cell cycle activity by activating cyclin D1, a protein that is upregulated in several PDAC cell lines $[63,64]$. In addition, NF-kB has been shown to induce IL-8, an inflammatory cytokine that is constitutively expressed at high levels in pancreatic cancer cells [53,65]. Chronic inflammation in $\mathrm{CP}$ activates transcription factors like NF-kB, which in effect induce inflammatory and oncogenic genes that promote cancer development.

Pancreatic stellate cells (PSCs), which are normally quiescent, regulate extracellular matrix production and pancreatic tissue architecture [66]. In response to cytokines and growth factors secreted by inflammatory cells, PSCs undergo functional changes to become myofibroblast-like cells that promote pancreatic injury and fibrosis [66-68]. Multiple in vitro and in vivo studies have proven the role of activated PSCs in fibrogenesis in $\mathrm{CP}$ [68]. Interestingly, agents that inhibit the activation of PSCs in vitro have shown promise in preventing the development of chronic pancreatitis [69-71]. Accumulating evidence suggests that PSCs may also promote the progression of pancreatic cancer [72]. In fact, activated PSCs play a pivotal role in pancreatic fibrogenesis and help create a desmoplastic reaction that favors oncogenesis [66]. In one in vitro study, PDAC cells induced the desmoplastic reaction by stimulating PSCs via soluble growth factors [68]. In addition, the study showed accelerated tumor growth in the presence of PSCs [68]. PSCs play an essential role in promoting fibrogenesis in $\mathrm{CP}$ and fostering the desmoplastic environment necessary for PDAC.

\section{Pancreatitis as an Initial Symptom of Pancreatic Cancer}

Over the past few decades, multiple studies have shown that AP might be one of the earliest manifestations of PDAC [73-76]. In fact, about one percent of AP cases are caused by PDAC $[9,77]$. The reported prevalence of AP prior to pancreatic cancer ranges between $1.4 \%$ and $6 \%$, and most cases of PDAC-induced AP follow a mild disease course $[75,78,79]$. 
A large population-based study looking at both Danish and US cohorts found that pancreatic head tumors were more frequent in patients with AP. They also found that tumors identified in patients presenting with AP were early stages of PDAC and more amenable to resection, leading to better survival compared to those with no history of AP [78]. These results were similar in a study by Dzeletovic et al., which showed lower cancer-related mortality in patients with history of AP preceding their cancer diagnosis. In addition, survival was better compared to that of patients with no AP history ( 325 days vs. 387 days; $p=0.003$ ) [80]. These observations were likely explained by earlier clinical presentations due to the painful nature of pancreatitis. Consequently, patients are diagnosed earlier, at a point where curative resections can be offered. Dzeletovic et al. concluded that $62 \%$ of patients with AP were able to undergo curative surgery compared to $43 \%$ in the non-pancreatitis group $(p=0.003)$. Comparative data from Lupinacci et al., which included PDAC patients who underwent a curative resection, found smaller tumor sizes $(<4 \mathrm{~cm})$ in patients presenting with $\mathrm{AP}$ compared to those in non-AP cases [81].

In contrast, Feng et al. investigated the survival rate in PDAC patients with moderate and severe AP compared to patients without AP. Their results showed a decrease in survival time in AP patients compared to that of patients with no prior pancreatitis [82]. However, this is explained by the impact of severe peripancreatic inflammation leading to difficult surgical resection with higher postoperative complications, hence poor survival [82,83]. A study by Li et al. investigated the optimal timing of surgical intervention in patients with AP with the goal of minimizing rates of postoperative complications. This work concluded that earlier surgery was significantly associated with postoperative complications, and the cutoff of 24.5 days was the optimal cutoff point for surgical resection $(p=0.025)$ [84]. However, the generalizability of this finding is limited by inclusion of patients with only a mild course of pancreatitis.

There are multiple predictors that were shown to be associated with PDAC in the setting of AP. Idiopathic pancreatitis was found to be a significant predictor in a large Danish cohort, with an adjusted hazard ratio of 2.52 (95\% CI: 1.83-3.47) [7]. Other important risk factors that were described in the literature were age higher than 50 at diagnosis of $\mathrm{AP}$, new-onset diabetes mellitus, and findings of $\mathrm{CP}$ at the time of $\mathrm{AP}$ diagnosis with alarm symptoms, including weight loss $[77,80]$. A Chinese study evaluating clinical predictors of underlying malignancy at the time of AP diagnosis found unexplained dilation of the main pancreatic to be highly suggestive of tumor presence (OR 417.83; 95\% CI: 80.40-2171.42). Interestingly, mild AP course was found to be a predictor of PDAC, but in contrast, severe pancreatitis was not associated with new PDAC diagnosis [77,79]. Therefore, presence of PDAC predictors in patients with unexplained AP should elevate clinicians' index of suspicion to aggressively evaluate and diagnose cancer early utilizing a combination of imaging and endoscopic modalities.

\section{Discussion}

PDAC remains a lethal disease with an extremely poor prognosis. According to the American Cancer Society 2019 data, approximately 56,770 people were diagnosed with and 45,750 died from PDAC in the United States. Unfortunately, PDAC disease incidence continues to grow by $0.5-1.0 \%$ annually, and by 2030, PDAC is projected to become the second leading cause of cancer-related mortality [3]. Accumulating and convincing evidence suggests that pancreatitis can be a sign of PDAC, but also might be a neoplastic precursor due to carcinogenesis either mediated by inflammatory processes or secondary to overlapping proinflammatory risk factors (e.g., smoking, alcohol use, diabetes mellitus, and obesity) that can further expedite cancer development [27]. It has been estimated that about $30 \%$ of PDAC could be prevented with the prevention of smoking [85]. Interestingly, the risk associated with smoking is reduced to the levels of a nonsmoker after 10 years of smoking cessation [85]. Moreover, dietary modification is important in preventing PDAC. Studies have shown that high consumption of red meat is associated with a greater risk of PDAC, whereas high fruit, vegetable, and nut intake is protective $[29,86,87]$. 
Therefore, the best preventive strategy against PDAC in patients with pancreatitis is risk reduction of modifiable risk factors.

Finally, it is important for clinicians to be able to risk-stratify and identify patients with PDAC earlier in their disease course in order to offer curative treatment. This requires special attention to older populations, patients with new diabetes mellitus diagnosis, smokers, and patients presenting with idiopathic pancreatitis. More studies are needed to establish guidelines and strategies in identifying these patients.

Author Contributions: T.A. and R.P. contributed equally to manuscript writing and original draft preparation; M.A., manuscript writing, review, and editing; M.A., supervision and critical revision of the manuscript for important intellectual content. All authors have read and agreed to the published version of the manuscript.

Funding: This research received no external funding.

Institutional Review Board Statement: Not applicable.

Informed Consent Statement: Not applicable.

Data Availability Statement: Data sharing not applicable.

Conflicts of Interest: The authors declare no conflict of interests.

\section{References}

1. Bray, F.; Ferlay, J.; Soerjomataram, I.; Siegel, R.L.; Torre, L.A.; Jemal, A. Global cancer statistics 2018: GLOBOCAN estimates of incidence and mortality worldwide for 36 cancers in 185 countries. CA Cancer J. Clin. 2018, 68, 394-424. [CrossRef] [PubMed]

2. Ilic, M.; Ilic, I. Epidemiology of pancreatic cancer. World J. Gastroenterol. 2016, 22, 9694-9705. [CrossRef]

3. Rahib, L.; Smith, B.D.; Aizenberg, R.; Rosenzweig, A.B.; Fleshman, J.M.; Matrisian, L.M. Projecting cancer incidence and deaths to 2030: The unexpected burden of thyroid, liver, and pancreas cancers in the United States. Cancer Res. 2014, 74, $2913-2921$. [CrossRef] [PubMed]

4. Rawla, P.; Sunkara, T.; Gaduputi, V. Epidemiology of Pancreatic Cancer: Global Trends, Etiology and Risk Factors. World J. Oncol. 2019, 10, 10-27. [CrossRef]

5. Hidalgo, M.; Cascinu, S.; Kleeff, J.; Labianca, R.; Löhr, J.M.; Neoptolemos, J.; Real, F.X.; Van Laethem, J.L.; Heinemann, V. Addressing the challenges of pancreatic cancer: Future directions for improving outcomes. Pancreatology 2015, 15, 8-18. [CrossRef] [PubMed]

6. Balkwill, F.; Mantovani, A. Inflammation and cancer: Back to Virchow? Lancet 2001, 357, 539-545. [CrossRef]

7. Kirkegard, J.; Cronin-Fenton, D.; Heide-Jorgensen, U.; Mortensen, F.V. Acute Pancreatitis and Pancreatic Cancer Risk: A Nationwide Matched-Cohort Study in Denmark. Gastroenterology 2018, 154, 1729-1736. [CrossRef]

8. Bansal, P.; Sonnenberg, A. Pancreatitis is a risk factor for pancreatic cancer. Gastroenterology 1995, 109, 247-251. [CrossRef]

9. Munigala, S.; Kanwal, F.; Xian, H.; Scherrer, J.F.; Agarwal, B. Increased risk of pancreatic adenocarcinoma after acute pancreatitis. Clin. Gastroenterol. Hepatol. 2014, 12, 1143-1150.e1. [CrossRef] [PubMed]

10. Chung, S.D.; Chen, K.Y.; Xirasagar, S.; Tsai, M.C.; Lin, H.C. More than 9-times increased risk for pancreatic cancer among patients with acute pancreatitis in Chinese population. Pancreas 2012, 41, 142-146. [CrossRef]

11. Sadr-Azodi, O.; Oskarsson, V.; Discacciati, A.; Videhult, P.; Askling, J.; Ekbom, A. Pancreatic Cancer Following Acute Pancreatitis: A Population-based Matched Cohort Study. Am. J. Gastroenterol. 2018, 113, 1711-1719. [CrossRef]

12. Zhang, X.; An, R.; Tian, H.; Zhao, J. Increased risk of pancreatic cancer after acute pancreatitis: A meta-analysis of prospective cohort studies. Clin. Res. Hepatol. Gastroenterol. 2019, 43, e39-e41. [CrossRef]

13. Liu, J.; Wang, Y.; Yu, Y. Meta-analysis reveals an association between acute pancreatitis and the risk of pancreatic cancer. World J. Clin. Cases 2020, 8, 4416-4430. [CrossRef]

14. Lowenfels, A.B.; Maisonneuve, P.; Cavallini, G.; Ammann, R.W.; Lankisch, P.G.; Andersen, J.R.; Dimagno, E.P.; Andren-Sandberg, A.; Domellof, L. Pancreatitis and the risk of pancreatic cancer. International Pancreatitis Study Group. N. Engl. J. Med. 1993, 328, 1433-1437. [CrossRef] [PubMed]

15. Malka, D.; Hammel, P.; Maire, F.; Rufat, P.; Madeira, I.; Pessione, F.; Levy, P.; Ruszniewski, P. Risk of pancreatic adenocarcinoma in chronic pancreatitis. Gut 2002, 51, 849-852. [CrossRef] [PubMed]

16. Raimondi, S.; Lowenfels, A.B.; Morselli-Labate, A.M.; Maisonneuve, P.; Pezzilli, R. Pancreatic cancer in chronic pancreatitis; aetiology, incidence, and early detection. Best Pract. Res. Clin. Gastroenterol. 2010, 24, 349-358. [CrossRef] [PubMed]

17. Talamini, G.; Falconi, M.; Bassi, C.; Sartori, N.; Salvia, R.; Caldiron, E.; Frulloni, L.; Di Francesco, V.; Vaona, B.; Bovo, P.; et al. Incidence of cancer in the course of chronic pancreatitis. Am. J. Gastroenterol. 1999, 94, 1253-1260. [CrossRef]

18. Ekbom, A.; McLaughlin, J.K.; Karlsson, B.M.; Nyrén, O.; Gridley, G.; Adami, H.O.; Fraumeni, J.F., Jr. Pancreatitis and pancreatic cancer: A population-based study. J. Natl. Cancer Inst. 1994, 86, 625-627. [CrossRef] [PubMed] 
19. Fernandez, E.; La Vecchia, C.; Porta, M.; Negri, E.; d'Avanzo, B.; Boyle, P. Pancreatitis and the risk of pancreatic cancer. Pancreas 1995, 11, 185-189. [CrossRef] [PubMed]

20. Rocca, G.; Gaia, E.; Iuliano, R.; Caselle, M.T.; Rocca, N.; Calcamuggi, G.; Emanuelli, G. Increased incidence of cancer in chronic pancreatitis. J. Clin. Gastroenterol. 1987, 9, 175-179. [CrossRef] [PubMed]

21. Iodice, S.; Gandini, S.; Maisonneuve, P.; Lowenfels, A.B. Tobacco and the risk of pancreatic cancer: A review and meta-analysis Langenbecks Arch. Surg. 2008, 393, 535-545. [CrossRef] [PubMed]

22. Bosetti, C.; Lucenteforte, E.; Silverman, D.T.; Petersen, G.; Bracci, P.M.; Ji, B.T.; Negri, E.; Li, D.; Risch, H.A.; Olson, S.H.; et al. Cigarette smoking and pancreatic cancer: An analysis from the International Pancreatic Cancer Case-Control Consortium (Panc4). Ann. Oncol. 2012, 23, 1880-1888. [CrossRef] [PubMed]

23. World Health Organization; International Agency for Research on Cancer. Tobacco Smoke and Involuntary Smoking; World Health Organization: Geneva, Switzerland, 2004; Volume 83, pp. 1-1438.

24. Kuzmickiene, I.; Everatt, R.; Virviciute, D.; Tamosiunas, A.; Radisauskas, R.; Reklaitiene, R.; Milinaviciene, E. Smoking and other risk factors for pancreatic cancer: A cohort study in men in Lithuania. Cancer Epidemiol. 2013, 37, 133-139. [CrossRef] [PubMed]

25. Mizuno, S.; Nakai, Y.; Isayama, H.; Kawahata, S.; Saito, T.; Takagi, K.; Watanabe, T.; Uchino, R.; Hamada, T.; Miyabayashi, K.; et al. Smoking, family history of cancer, and diabetes mellitus are associated with the age of onset of pancreatic cancer in Japanese patients. Pancreas 2014, 43, 1014-1017. [CrossRef]

26. Pelucchi, C.; Galeone, C.; Polesel, J.; Manzari, M.; Zucchetto, A.; Talamini, R.; Franceschi, S.; Negri, E.; La Vecchia, C. Smoking and body mass index and survival in pancreatic cancer patients. Pancreas 2014, 43, 47-52. [CrossRef]

27. Parkin, D.M.; Boyd, L.; Walker, L.C. 16. The fraction of cancer attributable to lifestyle and environmental factors in the UK in 2010. Br. J. Cancer 2011, 105 (Suppl. 2), S77-S81. [CrossRef]

28. Larsson, S.C.; Wolk, A. Red and processed meat consumption and risk of pancreatic cancer: Meta-analysis of prospective studies. Br. J. Cancer 2012, 106, 603-607. [CrossRef] [PubMed]

29. Wu, L.; Wang, Z.; Zhu, J.; Murad, A.L.; Prokop, L.J.; Murad, M.H. Nut consumption and risk of cancer and type 2 diabetes: A systematic review and meta-analysis. Nutr. Rev. 2015, 73, 409-425. [CrossRef] [PubMed]

30. Wu, Q.J.; Wu, L.; Zheng, L.Q.; Xu, X.; Ji, C.; Gong, T.T. Consumption of fruit and vegetables reduces risk of pancreatic cancer: Evidence from epidemiological studies. Eur. J. Cancer Prev. 2016, 25, 196-205. [CrossRef]

31. Aune, D.; Greenwood, D.C.; Chan, D.S.; Vieira, R.; Vieira, A.R.; Navarro Rosenblatt, D.A.; Cade, J.E.; Burley, V.J.; Norat, T. Body mass index, abdominal fatness and pancreatic cancer risk: A systematic review and non-linear dose-response meta-analysis of prospective studies. Ann. Oncol. 2012, 23, 843-852. [CrossRef]

32. Calle, E.E.; Rodriguez, C.; Walker-Thurmond, K.; Thun, M.J. Overweight, obesity, and mortality from cancer in a prospectively studied cohort of U.S. adults. N. Engl. J. Med. 2003, 348, 1625-1638. [CrossRef]

33. Maisonneuve, P.; Lowenfels, A.B. Risk factors for pancreatic cancer: A summary review of meta-analytical studies. Int. J. Epidemiol. 2015, 44, 186-198. [CrossRef] [PubMed]

34. Vincent, A.; Herman, J.; Schulick, R.; Hruban, R.H.; Goggins, M. Pancreatic cancer. Lancet 2011, 378, 607-620. [CrossRef]

35. di Magliano, M.P.; Logsdon, C.D. Roles for KRAS in pancreatic tumor development and progression. Gastroenterology 2013, 144, 1220-1229. [CrossRef] [PubMed]

36. Morton, J.P.; Timpson, P.; Karim, S.A.; Ridgway, R.A.; Athineos, D.; Doyle, B.; Jamieson, N.B.; Oien, K.A.; Lowy, A.M.; Brunton, V.G.; et al. Mutant p53 drives metastasis and overcomes growth arrest/senescence in pancreatic cancer. Proc. Natl. Acad. Sci. USA 2010, 107, 246-251. [CrossRef]

37. Everhart, J.; Wright, D. Diabetes mellitus as a risk factor for pancreatic cancer. A meta-analysis. Jama 1995, $273,1605-1609$. [CrossRef]

38. Huxley, R.; Ansary-Moghaddam, A.; Berrington de González, A.; Barzi, F.; Woodward, M. Type-II diabetes and pancreatic cancer: A meta-analysis of 36 studies. Br. J. Cancer 2005, 92, 2076-2083. [CrossRef] [PubMed]

39. Ben, Q.; Xu, M.; Ning, X.; Liu, J.; Hong, S.; Huang, W.; Zhang, H.; Li, Z. Diabetes mellitus and risk of pancreatic cancer: A meta-analysis of cohort studies. Eur. J. Cancer 2011, 47, 1928-1937. [CrossRef] [PubMed]

40. Fan, Y.; Hu, J.; Feng, B.; Wang, W.; Yao, G.; Zhai, J.; Li, X. Increased Risk of Pancreatic Cancer Related to Gallstones and Cholecystectomy: A Systematic Review and Meta-Analysis. Pancreas 2016, 45, 503-509. [CrossRef]

41. Genkinger, J.M.; Spiegelman, D.; Anderson, K.E.; Bergkvist, L.; Bernstein, L.; van den Brandt, P.A.; English, D.R.; Freudenheim, J.L.; Fuchs, C.S.; Giles, G.G.; et al. Alcohol intake and pancreatic cancer risk: A pooled analysis of fourteen cohort studies. Cancer Epidemiol. Biomarkers Prev. 2009, 18, 765-776. [CrossRef] [PubMed]

42. Yadav, D.; Lowenfels, A.B. The epidemiology of pancreatitis and pancreatic cancer. Gastroenterology 2013, $144,1252-1261$. [CrossRef] [PubMed]

43. Duell, E.J.; Lucenteforte, E.; Olson, S.H.; Bracci, P.M.; Li, D.; Risch, H.A.; Silverman, D.T.; Ji, B.T.; Gallinger, S.; Holly, E.A.; et al. Pancreatitis and pancreatic cancer risk: A pooled analysis in the International Pancreatic Cancer Case-Control Consortium (PanC4). Ann. Oncol. 2012, 23, 2964-2970. [CrossRef]

44. Carriere, C.; Young, A.L.; Gunn, J.R.; Longnecker, D.S.; Korc, M. Acute pancreatitis markedly accelerates pancreatic cancer progression in mice expressing oncogenic Kras. Biochem. Biophys Res. Commun. 2009, 382, 561-565. [CrossRef] 
45. Minato, Y.; Kamisawa, T.; Tabata, T.; Hara, S.; Kuruma, S.; Chiba, K.; Kuwata, G.; Fujiwara, T.; Egashira, H.; Koizumi, K.; et al. Pancreatic cancer causing acute pancreatitis: A comparative study with cancer patients without pancreatitis and pancreatitis patients without cancer. J. Hepatobiliary Pancreat. Sci. 2013, 20, 628-633. [CrossRef]

46. Coussens, L.M.; Werb, Z. Inflammation and cancer. Nature 2002, 420, 860-867. [CrossRef]

47. Grivennikov, S.I.; Greten, F.R.; Karin, M. Immunity, inflammation, and cancer. Cell 2010, 140, 883-899. [CrossRef] [PubMed]

48. Greten, F.R.; Grivennikov, S.I. Inflammation and Cancer: Triggers, Mechanisms, and Consequences. Immunity 2019, 51, 27-41. [CrossRef] [PubMed]

49. Farrow, B.; Evers, B.M. Inflammation and the development of pancreatic cancer. Surg. Oncol. 2002, 10, 153-169. [CrossRef]

50. Kong, X.; Sun, T.; Kong, F.; Du, Y.; Li, Z. Chronic Pancreatitis and Pancreatic Cancer. Gastrointest Tumors 2014, 1, 123-134. [CrossRef]

51. Kandikattu, H.K.; Venkateshaiah, S.U.; Mishra, A. Chronic Pancreatitis and the Development of Pancreatic Cancer. Endocr. Metab. Immune Disord. Drug Targets 2020, 20, 1182-1210. [CrossRef]

52. Friess, H.; Guo, X.Z.; Nan, B.C.; Kleeff, J.; Büchler, M.W. Growth factors and cytokines in pancreatic carcinogenesis. Ann. N. Y. Acad. Sci. 1999, 880, 110-121. [CrossRef]

53. Le, X.; Shi, Q.; Wang, B.; Xiong, Q.; Qian, C.; Peng, Z.; Li, X.C.; Tang, H.; Abbruzzese, J.L.; Xie, K. Molecular regulation of constitutive expression of interleukin-8 in human pancreatic adenocarcinoma. J. Interferon Cytokine Res. 2000, 20, 935-946. [CrossRef] [PubMed]

54. Kalthoff, H.; Roeder, C.; Brockhaus, M.; Thiele, H.G.; Schmiegel, W. Tumor necrosis factor (TNF) up-regulates the expression of p75 but not p55 TNF receptors, and both receptors mediate, independently of each other, up-regulation of transforming growth factor alpha and epidermal growth factor receptor mRNA. J. Biol. Chem. 1993, 268, 2762-2766. [CrossRef]

55. McDade, T.P.; Perugini, R.A.; Vittimberga, F.J., Jr.; Carrigan, R.C.; Callery, M.P. Salicylates inhibit NF-kappaB activation and enhance TNF-alpha-induced apoptosis in human pancreatic cancer cells. J. Surg. Res. 1999, 83, 56-61. [CrossRef]

56. Razidlo, G.L.; Burton, K.M.; McNiven, M.A. Interleukin-6 promotes pancreatic cancer cell migration by rapidly activating the small GTPase CDC42. J. Biol. Chem. 2018, 293, 11143-11153. [CrossRef] [PubMed]

57. Mace, T.A.; Shakya, R.; Pitarresi, J.R.; Swanson, B.; McQuinn, C.W.; Loftus, S.; Nordquist, E.; Cruz-Monserrate, Z.; Yu, L.; Young, G.; et al. IL-6 and PD-L1 antibody blockade combination therapy reduces tumour progression in murine models of pancreatic cancer. Gut 2018, 67, 320-332. [CrossRef]

58. Taniguchi, K.; Karin, M. NF-кB, inflammation, immunity and cancer: Coming of age. Nat. Rev. Immunol. 2018, 18, 309-324. [CrossRef]

59. Xia, Y.; Shen, S.; Verma, I.M. NF-kB, an active player in human cancers. Cancer Immunol. Res. 2014, 2, 823-830. [CrossRef]

60. Huang, H.; Liu, Y.; Daniluk, J.; Gaiser, S.; Chu, J.; Wang, H.; Li, Z.S.; Logsdon, C.D.; Ji, B. Activation of nuclear factor-kB in acinar cells increases the severity of pancreatitis in mice. Gastroenterology 2013, 144, 202-210. [CrossRef]

61. Wang, W.; Abbruzzese, J.L.; Evans, D.B.; Larry, L.; Cleary, K.R.; Chiao, P.J. The nuclear factor-kappa B RelA transcription factor is constitutively activated in human pancreatic adenocarcinoma cells. Clin. Cancer Res. 1999, 5, 119-127.

62. Prabhu, L.; Mundade, R.; Korc, M.; Loehrer, P.J.; Lu, T. Critical role of NF-kB in pancreatic cancer. Oncotarget 2014, 5, 10969-10975. [CrossRef] [PubMed]

63. Yamamoto, Y.; Gaynor, R.B. Therapeutic potential of inhibition of the NF-kappaB pathway in the treatment of inflammation and cancer. J. Clin. Investig. 2001, 107, 135-142. [CrossRef] [PubMed]

64. Kornmann, M.; Ishiwata, T.; Itakura, J.; Tangvoranuntakul, P.; Beger, H.G.; Korc, M. Increased cyclin D1 in human pancreatic cancer is associated with decreased postoperative survival. Oncology 1998, 55, 363-369. [CrossRef] [PubMed]

65. Shi, Q.; Le, X.; Abbruzzese, J.L.; Wang, B.; Mujaida, N.; Matsushima, K.; Huang, S.; Xiong, Q.; Xie, K. Cooperation between transcription factor AP-1 and NF-kappaB in the induction of interleukin-8 in human pancreatic adenocarcinoma cells by hypoxia. J. Interferon Cytokine Res. 1999, 19, 1363-1371. [CrossRef]

66. Jin, G.; Hong, W.; Guo, Y.; Bai, Y.; Chen, B. Molecular Mechanism of Pancreatic Stellate Cells Activation in Chronic Pancreatitis and Pancreatic Cancer. J. Cancer 2020, 11, 1505-1515. [CrossRef] [PubMed]

67. Phillips, P. Pancreatic stellate cells and fibrosis. In Pancreatic Cancer and Tumor Microenvironment; Grippo, P.J., Munshi, H.G., Eds.; Transworld Research Network Copyright (c) 2021; Transworld Research Network: Trivandrum, India, 2012.

68. Bachem, M.G.; Schunemann, M.; Ramadani, M.; Siech, M.; Beger, H.; Buck, A.; Zhou, S.; Schmid-Kotsas, A.; Adler, G. Pancreatic carcinoma cells induce fibrosis by stimulating proliferation and matrix synthesis of stellate cells. Gastroenterology 2005, 128, 907-921. [CrossRef]

69. Kuno, A.; Yamada, T.; Masuda, K.; Ogawa, K.; Sogawa, M.; Nakamura, S.; Nakazawa, T.; Ohara, H.; Nomura, T.; Joh, T.; et al. Angiotensin-converting enzyme inhibitor attenuates pancreatic inflammation and fibrosis in male Wistar Bonn/Kobori rats. Gastroenterology 2003, 124, 1010-1019. [CrossRef] [PubMed]

70. Talukdar, R.; Tandon, R.K. Pancreatic stellate cells: New target in the treatment of chronic pancreatitis. J. Gastroenterol. Hepatol. 2008, 23, 34-41. [CrossRef]

71. Shimizu, K.; Shiratori, K.; Hayashi, N.; Kobayashi, M.; Fujiwara, T.; Horikoshi, H. Thiazolidinedione derivatives as novel therapeutic agents to prevent the development of chronic pancreatitis. Pancreas 2002, 24, 184-190. [CrossRef]

72. Pandol, S.; Edderkaoui, M.; Gukovsky, I.; Lugea, A.; Gukovskaya, A. Desmoplasia of pancreatic ductal adenocarcinoma. Clin. Gastroenterol. Hepatol. 2009, 7, S44-S47. [CrossRef] 
73. Lin, A.; Feller, E.R. Pancreatic carcinoma as a cause of unexplained pancreatitis: Report of ten cases. Ann. Intern. Med. 1990, 113, 166-167. [CrossRef] [PubMed]

74. Gambill, E.E. Pancreatitis associated with pancreatic carcinoma: A study of 26 cases. Mayo Clin. Proc. 1971, 46, 174-177. [PubMed]

75. Mujica, V.R.; Barkin, J.S.; Go, V.L. Acute pancreatitis secondary to pancreatic carcinoma. Study Group Participants. Pancreas 2000, 21, 329-332. [CrossRef] [PubMed]

76. Köhler, H.; Lankisch, P.G. Acute pancreatitis and hyperamylasaemia in pancreatic carcinoma. Pancreas 1987, 2, 117-119. [CrossRef] [PubMed]

77. Kirkegård, J.; Mortensen, F.V.; Heide-Jørgensen, U.; Cronin-Fenton, D. Predictors of underlying pancreatic cancer in patients with acute pancreatitis: A Danish nationwide cohort study. HPB 2020, 22, 553-562. [CrossRef]

78. Kirkegard, J.; Gaber, C.; Lund, J.L.; Hinton, S.P.; Ladekarl, M.; Heide-Jorgensen, U.; Cronin-Fenton, D.; Mortensen, F.V. Acute pancreatitis as an early marker of pancreatic cancer and cancer stage, treatment, and prognosis. Cancer Epidemiol. 2020, 64, 101647. [CrossRef]

79. Xiong, Y.; Zhao, Y.; Han, X.; Chen, G.; Windsor, J.; Wu, D.; Qian, J. Clinical characteristics and outcome of tumor-associated acute pancreatitis: A single-center cohort study. Ann. Transl. Med. 2021, 9, 639. [CrossRef] [PubMed]

80. Dzeletovic, I.; Harrison, M.E.; Crowell, M.D.; Pannala, R.; Nguyen, C.C.; Wu, Q.; Faigel, D.O. Pancreatitis before pancreatic cancer: Clinical features and influence on outcome. J. Clin. Gastroenterol. 2014, 48, 801-805. [CrossRef]

81. Lupinacci, R.M.; Faron, M.; Bachellier, P.; Sauvanet, A.; Beauchet, A.; Le Treut, Y.P.; Adham, M.; Mabrut, J.Y.; Delpero, J.R.; Paye, F. Acute Pancreatitis as the Initial Presentation of Pancreatic Adenocarcinoma does not Impact Short- and Long-term Outcomes of Curative Intent Surgery: A Study of the French Surgical Association. World J. Surg. 2021, 45, 3146-3156. [CrossRef]

82. Feng, Q.; Li, C.; Zhang, S.; Tan, C.L.; Mai, G.; Liu, X.B.; Chen, Y.H. Recurrence and survival after surgery for pancreatic cancer with or without acute pancreatitis. World J. Gastroenterol. 2019, 25, 6006-6015. [CrossRef] [PubMed]

83. Chen, Y.H.; Xie, S.M.; Zhang, H.; Tan, C.L.; Ke, N.W.; Mai, G.; Liu, X.B. Clinical impact of preoperative acute pancreatitis in patients who undergo pancreaticoduodenectomy for periampullary tumors. World J. Gastroenterol. 2015, 21, 6937-6943. [CrossRef] [PubMed]

84. Li, S.; Tian, B. Acute pancreatitis in patients with pancreatic cancer: Timing of surgery and survival duration. Medicine 2017, 96, e5908. [CrossRef] [PubMed]

85. Vrieling, A.; Bueno-de-Mesquita, H.B.; Boshuizen, H.C.; Michaud, D.S.; Severinsen, M.T.; Overvad, K.; Olsen, A.; Tjønneland, A.; Clavel-Chapelon, F.; Boutron-Ruault, M.C.; et al. Cigarette smoking, environmental tobacco smoke exposure and pancreatic cancer risk in the European Prospective Investigation into Cancer and Nutrition. Int. J. Cancer 2010, 126, 2394-2403. [CrossRef]

86. Lightsey, D. Comment on 'Red and processed meat consumption and risk of pancreatic cancer: Meta-analysis of prospective studies'. Br. J. Cancer 2012, 107, 754-755. [CrossRef]

87. Paluszkiewicz, P.; Smolińska, K.; Dębińska, I.; Turski, W.A. Main dietary compounds and pancreatic cancer risk. The quantitative analysis of case-control and cohort studies. Cancer Epidemiol. 2012, 36, 60-67. [CrossRef] 